\title{
Surfactant-Enhanced Washing of Soils Contaminated with Wasted-Automotive Oils and the Quality of the Produced Wastewater
}

\author{
Montserrat Zacarias-Salinas ${ }^{1}$, Mabel Vaca ${ }^{2}$, Miguel A. Flores ${ }^{2}$, Erick R. Bandala ${ }^{3}$, Luis G. Torres ${ }^{{ }^{*}}$ \\ ${ }^{1}$ UPIBI-Instituto Politécnico Nacional. Av. Acueducto s.n. Colonia Barrio la Laguna Ticomán. México DF, México; ${ }^{2}$ Labor- \\ atorio de Calidad de Agua y Residuos, Universidad Autónoma Metropolitana-Unidad Azcapotzalco México; ${ }^{3}$ Departamento de \\ Ingeniería Civil y Ambiental Escuela de Ingeniería, Universidad de las Américas-Puebla. Sta. Catarina Mártir, Cholula, Puebla, \\ México. \\ Email: ${ }^{*}$ TTorresBustillos@gmail.com
}

Received February $16^{\text {th }}, 2013$; revised March $19^{\text {th }}, 2013$; accepted April $15^{\text {th }}, 2013$

Copyright (C) 2013 Montserrat Zacarias-Salinas et al. This is an open access article distributed under the Creative Commons Attribution License, which permits unrestricted use, distribution, and reproduction in any medium, provided the original work is properly cited. In accordance of the Creative Commons Attribution License all Copyrights (C) 2013 are reserved for SCIRP and the owner of the intellectual property Montserrat Zacarias-Salinas et al. All Copyright (C) 2013 are guarded by law and by SCIRP as a guardian.

\begin{abstract}
An old automotive industrial site located at Mexico City with many years of operation and contaminated with heavy oil hydrocarbons, particularly spent oils, was assessed for restoration using the surfactant enhanced soil washing (SESW) process. The main goal of this study was to characterize the contaminated soil in terms of TPHs, BTEX, PAHs, and metals contents as well as microbiologically (total heterotrophs and specific degrading microorganisms). We also aimed to determine the surfactant type and concentration to be used in the SESW process for the automotive waste oil contaminated soil. At the end, sixteen $\mathrm{kg}$ of contaminated soil were washed and the produced wastewater (approximately $40 \mathrm{~L}$ ) was characterized in terms of COD, BOD; solids, and other physico-chemical parameters. The soil contained about $14,000 \mathrm{mg}$ of TPH$/ \mathrm{kg}$ soil (heavy fraction), $0.13 \mathrm{mg} / \mathrm{kg}$ of benzo (k) fluoranthene and $0.07 \mathrm{mg} / \mathrm{kg}$ of benzo (a) pyrene as well as traces of some metals. Metals concentrations were always under the maximum concentration levels suggested by Mexican regulations. 15 different surfactants were used to identify the one with the capability to achieve the highest TPH removal. Surfactants included 5 anionics, 2 zwitterionic, 5 nonionics and 3 natural gums. Sulfopon 30 at a concentration of $0.5 \%$ offered the best surfactant performance. The TPH removals employing the different surfactants were in the range from $38 \%$ to $68 \%$, in comparison to the soil washing with water ( $10 \%$ of TPH removal). Once the surfactant was selected, $70 \mathrm{~kg}$ of soil were washed and the resulting water contained approximately $1300 \mathrm{mg} / \mathrm{L}$ of $\mathrm{COD}, 385 \mathrm{mg} / \mathrm{L}$ of BOD $(\mathrm{BOD} / \mathrm{COD}=0.29), 122 \mathrm{mg} / \mathrm{L}$ of MBAS, and $212 \mathrm{mg} / \mathrm{L}$ of oil and greases, among other contaminants.
\end{abstract}

Keywords: Wasted Automotive Oils; Surfactants; Soil Washing; Waste Water

\section{Introduction}

The restoration of soil contaminated with hydrocarbons is often difficult and complex due, among other, to the adsorption on the soil matrix and the low solubility of these contaminants. It has been demonstrated that the more insoluble in water is the contaminant, the longer it remains in the soil matrix [1].

Many different techniques have been reported to restore soils contaminated with hydrocarbons; among of

\footnotetext{
"Corresponding author.
}

them the surfactant-enhanced soil washing (SESW) have recently emerged as highly cost-effective [2-4]. Surfactants reduce surface tension and form aggregates (i.e. micelles in aqueous solution), changing surface tension as result of surfactant's concentration on the solution's surface. Contaminants present in soil are removed by means of two phenomena: 1) The solubilization of compounds due to the reduction of surface tension (bellow the surfactant's critical micelle concentration (CMC) and 2) The mobilization of hydrophobic compounds due to the presence of the surfactant, at concentrations higher 
than surfactant's CMC value [5].

SESW process has shown very good results, and also has been considered as an economic and easy technique, so its application has increased in interest [3,6-9] as shown the literature review. Iturbe et al. [6] reported TPH (Total Petroleum Hydrocarbons) removals over $92 \%$ for contaminated soil with an initial concentration up to $17,238 \mathrm{mg} / \mathrm{kg}$, when washing contaminated soils using the surfactant Canarcel TW80 in concentrations of about $0.5 \%$. In other studies with SDS (sodium dodecyl sulphate), TPH removals above $90 \%$ were reported when treating oil-hydrocarbons contaminated soils [10].

Chin-Chi et al. [11], when washing contaminated soil, showed high TPH removals, between $63 \%$ and $62 \%$, respectively using biosurfactants (i.e. rhamnolopids and surfactin) for the SESW process in a soil contaminated with a $9000 \mathrm{mg} / \mathrm{kg}$ of hydrocarbons. These authors also used two synthetic surfactants (Triton X-100 and Tween 80 ) for the same washing process, finding that synthetic surfactants were clearly less efficient $(40 \%$ and $35 \%$, removal, respectively). Another experiment using a nonionic surfactant Brij 35 showed removals of crude oil from soils of $93.54 \%$ in a surfactant-enhanced washing of soil contaminated with $50,000 \mathrm{mg} / \mathrm{kg}$ of crude oil [12].

In this work, an old automotive industrial site located at Mexico City was assessed for restoration using SESW. The site maintains operations for many years and produced contamination with heavy oil hydrocarbons, in particular spent oils. Car service activities were carried out in the place, such as automotive oil change service, and wasted oils were stored in a submerged cement tank for many years. The company suspended its service more than 10 years ago and closed. The place was dismantled to become a residential zone.

During the process of characterization the site, which was carried out by the UAM-Azcapotzalco (Mexico), it was noticed that the oil cement tank suffered spills causing infiltration of the automotive oil waste in a large area of the old industry, contaminating the subsoil in an important extent. The soil contained about $14,000 \mathrm{mg}$ of $\mathrm{TPH} / \mathrm{kg}$ soil referring to heavy fraction (The analysis of the TPHs present in the soil was made by the suggested methodology in Mexican standard using dry soil). The maximum permissible limit established by Mexican regulations concerning contaminated soil with heavy fraction petroleum hydrocarbons suggests reducing the concentration of the site up to $6000 \mathrm{mg} / \mathrm{kg}$.

The main goal of this study was to characterize the sub-soil of the old automotive industry, in terms of TPHs, BTEX (benzene, toluene, ethylbenzene and xylene), PAHs (polycyclic aromatic hydrocarbons), and a set of metals as well as microbiologically. To show the suitability of SESW process to remediate the site, including surfactant type selection and concentration to be used in the processes. Finally, the generated wastewater was characterized in terms of COD (chemical oxygen demand), BOD (biochemical oxygen demand), solids, and other parameters in order to determine the kind of process most suitable to treat the effluent to recycle the water into the soil washing process or to be disposed at the end of the soil remediation process.

\section{Materials and Methods}

\subsection{Soil Sampling}

The soil samples were taken from the subsoil of the site using a 25 SCRS Giddings model hydraulic punch (Figure 1), taking samples from 1.5 to $3.0 \mathrm{~m}$ deep, extracting about 70 kilograms of wet soil, which were stored in polypropylene black bags to avoid photo-degradation of pollutants and placed into pet boxes were they were maintained at room temperature during a period of 2 weeks before the experiments. Soil was thoroughly mixed to assure that concentrations of TPH as well as other organic and inorganic components were uniform for the whole batch of soil.

\subsection{Soil Characterization}

The composed soil sample was dried at room temperature for 3 days. The final moisture content in the soil was determined $10 \%$, measured by mass difference. The physico-chemical characterization of the soil was carried out including texture, bulk and particle density, pore space, total and bioavailable nitrogen and phosphorus and conductivity measurements. TPH's, the $16 \mathrm{PAH}$ (Polycyclic aromatic hydrocarbons) normed by USEPA and BTEX were also determined. Finally, some metals and metalloids concentrations ( $\mathrm{Na}, \mathrm{K}, \mathrm{Ca}, \mathrm{Mg}, \mathrm{As}, \mathrm{Cd}$, $\mathrm{Zn}, \mathrm{Cu}, \mathrm{Cr}, \mathrm{Pb}, \mathrm{Ni}, \mathrm{Hg}$ and $\mathrm{Fe}$ ), were determined in the soil sample. The analyses were performed based on EPA

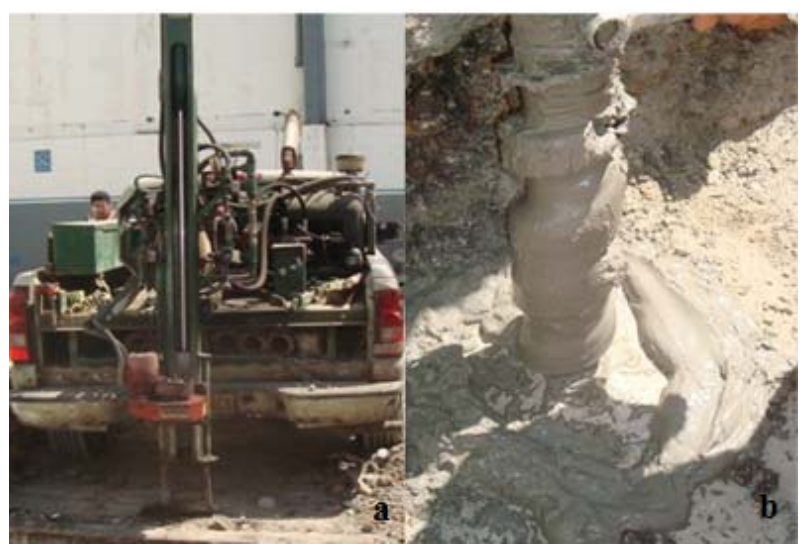

Figure 1. (a) Hydraulic punch employed at the sampling process; (b) Helicoidal drilling device. 
standard methodology suggested in Mexican regulations, for TPH content the methods were EPA 9071B and EPA1664A.

The microbiological assessments were applied to the contaminated soil in order to determine the amount of present microorganisms. Plate counts were carried out using nutritive agar Petri dishes for heterotrophic bacteria count and for hydrocarbon degrading bacteria, diesel, gasoline or automotive-oil waste was employed as carbon source. The mineral medium used was as follows (in $\mathrm{mg} / \mathrm{L}): \mathrm{KH}_{2} \mathrm{PO}_{4}, 8.5 ; \mathrm{K}_{2} \mathrm{HPO}_{4}, 21.75 ; \mathrm{Na}_{2} \mathrm{HPO}_{4} * 7 \mathrm{H}_{2} \mathrm{O}$, 33.4; $\mathrm{NH}_{4} \mathrm{Cl}, 1.7 ; \mathrm{MgSO}_{4} * 7 \mathrm{H}_{2} \mathrm{O}, 22.5 \mathrm{CaCl}_{2}, 27.5$; $\mathrm{FeCl}_{3} * 6 \mathrm{H}_{2} \mathrm{O}, 0.25$. These mineral media was adapted from the one suggested in a Mexican standard employed to determine BOD (NMX-AA-028 in NOM-001-SEMARNAT-1996). The bacteria were incubated at $30^{\circ} \mathrm{C}$ over a period of 48 to 96 hours for heterotrophic and hydrocarbon degrading bacteria. The quantities of bacteria were expressed as a CFU/g of dry soil.

\subsection{Washing Solutions}

Five anionic surfactants were used: sodium dodecyl sulfate (SDS), sodium bencen-dodecyl sulfonate (SDBS), Texapon N40 (TN40), Sulfopon30 (S30) and Surfacpol A14104. The five nonionic surfactants employed along this work were Tween 80 (TW80), Tween 20 (TW20), Span 80 (SP80), Brij 35 (B35) and Emulgin W600 (EW). Two zwitterionic products were employed: Polafix CAPB and Polafix LO. Finally, three natural gums (capable to act as a surfactants/emulsifiers) were employed, i.e., locust bean gum (LGB), guar gum $(\mathrm{G})$ and mezquite seed gum (MZ). Distillated water was used as a blank for soil washing assessments. Some characteristics of the employed surfactants are shown in Table 1.

Two sets of soil washing experiments were performed; the first set was carried out using synthetic surfactants (anionic, nonionic and zwitterionic) concentrations of $0.5 \%$ and $0.1 \%$ for natural gums. In the second set of assessments, different concentrations of surfactants were tested of $0.25 \%, 0.5 \%$ and $1 \%$ for the synthetics surfactants and $0.05 \%, 0.1 \%$ and $0.2 \%$ for natural gums.

\subsection{Soil Washing}

The SESW experiments were carried out in $40 \mathrm{~mL}$ glass vials, where $6 \mathrm{~g}$ of contaminated soil dried at room temperature were added together with $20 \mathrm{~mL}$ of the washing solution or water. The vials were shaken at $200 \mathrm{rpm}$ for a period of 23 hours and, then, they allowed to settle for an hour.

\subsection{Measurement of TPH's in Soil Washing}

After washing the soils, supernatant was separated and stored in the freezer until further analysis. The washed soil samples were placed in aluminum trays to be dried at room temperature $\left(25^{\circ} \mathrm{C}\right)$ for 3 days. Then TPH's concentration was determined by a gravimetric method after Soxhlet extraction using hexane as a solvent, described in Section 2.2. Soil humidity was determined and taken into account to report mg of heavy fraction/g of dry soil using the methodology suggested in Mexican standards.

Table 1. Some characteristics of the employed syntetic surfactants.

\begin{tabular}{|c|c|c|c|c|c|c|}
\hline Surfactant & Ionic nature & Chemical name & Mol weight (g/gmol) & HLB & $\mathrm{CMC}(\mathrm{mg} / \mathrm{L})$ & Reference \\
\hline SDS & Anionic & Sodium dodecyl sulfate & 288.4 & 40 & 400 & {$[13]$} \\
\hline SDBS & Anionic & Sodium dodecyl-bencenesulfonate & 322.37 & NR & 1.5 & {$[14]$} \\
\hline Texapon 40 & Anionic & Sodium lauryl ether sulphonate & 442 & NR & 1458 & {$[13]$} \\
\hline Sulfopon 30 & Anionic & Sodium lauryl sulphate & 272 & NR & 150 & This work \\
\hline Surfacpol A14104 & Anionic & NR & NR & NR & NR & {$[14]$} \\
\hline Tween 80 & Non-ionic & Sorbitan monoleate (Poe 20) & 1308 & 15 & 65.4 & {$[13]$} \\
\hline Tween 20 & Non-ionic & Sorbitan monolaurate & 1226 & 16.7 & 60.74 & {$[13]$} \\
\hline Span 80 & Non-ionic & Sorbitan monooleate & 428 & NR & $\mathrm{NR}$ & \\
\hline Emulgin W600 & Non-ionic & Nonyl phenol & 483 & 11 & 45.06 & {$[13]$} \\
\hline Polafix CAPB & Zwitterionic & Cocoamide-propyl Betaine & NR & NR & 80 & {$[14]$} \\
\hline Polafix LO & Zwitterionic & NR & NR & NR & NR & - \\
\hline
\end{tabular}

HLB: Hydrophilic Lipophilic Balance; CMC: Critical Micelle Concentration; NR: Not Reported. 


\section{Results and Discussion}

\subsection{Soil Characterization}

Table 2 shows some of the physical and chemical characteristics of the soil employed in this study. As shown the content of organic matter, nitrogen and phosphorus; are interesting because suggest the possibility of applying biological treatment to the resulting waste water. The moisture content of the soil was $40 \%$. The conductivity of the soil was normal in the case of a clayish soil $(0.3058 \mu \mathrm{S} / \mathrm{cm})$, as well as the pore space percentage $(66 \%)$. The report suggests that $\mathrm{pH}$ is mildly basic. The organic matter content indicates a moderately rich soil. However, the nitrogen content in the soil is poor, contrasting with the very high contents of phosphorus. Metals and metalloids concentrations in soil (Table 2), were reported were below the limits set in Mexican regulation.

Two bacteria count processes were applied to the contaminated soil, heterotrophs and hydrocarbon degraders (diesel, petroleum and automotive oil waste). The results showed an heterotrophic microorganisms count of $4.1 \times$ $10^{7} \mathrm{CFU} / \mathrm{g}$. Regarding the specific degraders, values of 1 $\times 10^{8} \mathrm{CFU} / \mathrm{g}, 1.5 \times 10^{8} \mathrm{CFU} / \mathrm{g}$ and $1 \times 10^{8} \mathrm{CFU} / \mathrm{g}$ were found for diesel, petroleum and automotive waste oil degraders, respectively. The microbial count was similar to that reported by Iturbe et al. [6] for a soil contaminated with PAHs where bacteria counts of $1.8 \times 10^{8}$ $\mathrm{CFU} / \mathrm{g}$ for heterotrophic and $5.4 \times 10^{8} \mathrm{CFU} / \mathrm{g}, 1 \times 10^{8}$ $\mathrm{CFU} / \mathrm{g}$ and $5.6 \times 10^{8} \mathrm{CFU} / \mathrm{g}$ for diesel, petroleum and spent oil bacteria were reported. These values are higher

Table 2. Physicochemical characteristics of the contaminated soils.

\begin{tabular}{cccc}
\hline Parameter & Result & Parameter & Result \\
\hline Conductivity & $0.3058 \mu \mathrm{S} / \mathrm{cm}$ & $\mathrm{Pb}$ & $19.32 \mathrm{mg} / \mathrm{kg}$ \\
$\mathrm{pH}$ & 8.5 & $\mathrm{Fe}$ & $4432.65 \mathrm{mg} / \mathrm{kg}$ \\
Apparent density & $1.02 \mathrm{~g} / \mathrm{cm}^{3}$ & $\mathrm{Zn}$ & $13.60 \mathrm{mg} / \mathrm{kg}$ \\
Bulk density & $3.0 \mathrm{~g} / \mathrm{cm}^{3}$ & $\mathrm{Na}$ & $652.22 \mathrm{mg} / \mathrm{kg}$ \\
Void space & $66 \%$ & $\mathrm{~K}$ & $949.65 \mathrm{mg} / \mathrm{kg}$ \\
Soil percentual & $60 \% \mathrm{clay}$ & $\mathrm{Ca}$ & $23855.82 \mathrm{mg} / \mathrm{kg}$ \\
composition & $30 \% \mathrm{silt}$ & $\mathrm{Mg}$ & $14401.59 \mathrm{mg} / \mathrm{kg}$ \\
Texture & $10 \% \mathrm{sand}$ & $\mathrm{As}$ & $1.78 \mathrm{mg} / \mathrm{kg}$ \\
Organic matter & $2.12 \%$ & $\mathrm{Cd}$ & $2.80 \mathrm{mg} / \mathrm{kg}$ \\
Total phosphorus & $605.60 \mathrm{mg} / \mathrm{kg}$ & $\mathrm{Cr}$ & $<1.0 \mathrm{mg} / \mathrm{kg}$ \\
Available & $18.80 \mathrm{mg} / \mathrm{kg}$ & $\mathrm{Ni}$ & $9.87 \mathrm{mg} / \mathrm{kg}$ \\
phosphorus & & & \\
Total nitrogen & $0.058 \%$ & $\mathrm{Hg}$ & $0.11 \mathrm{mg} / \mathrm{kg}$ \\
Avail. nitrogen & $9.93 \mathrm{mg} / \mathrm{kg}$ & & \\
\hline
\end{tabular}

than those reported by Bogardt and Hemmingsen [15] for soils contaminated with diesel and petroleum oil $(1.9 \times$ $10^{7} \mathrm{CFU} / \mathrm{g}$ and $3.3 \times 10^{7} \mathrm{CFU} / \mathrm{g}$, respectively). On the other hand, Hernández-Espriu et al. [16] reported a bacterial count of $2 \times 10^{11} \mathrm{FCU} / \mathrm{g}$ for an agricultural soil contaminated with diesel. The observed amounts of microorganisms are higher than the minimum necessary for biodegradation process $\left(10^{4}\right)$ stated by Fahnestock $[6,16]$.

Regarding the analysis of PAHs, BTEX and TPHs, it was found that only the heavy fraction hydrocarbons exceeded the permissible limits established by Mexican legislation (Table 3). No BTEX were determined over the method detection limit and only two PAHs were found from the 16 PAH's regulated by USEPA. These PAHs, however, were found with concentrations below the maximum permissible limits established in the Mexican standards (Table 4). No light fraction oil content in the media was found indicating that the contamination was due solely to automotive waste-oil spills.

Despite the good performance and applications of surfactants for the transference of hydrocarbons into water, the removal efficiency depends also on several factors including nature, amount of surfactants, age of contaminated soil, soil properties and surfactant/oil/soil system behavior [10]. The highest removals were observed for

Table 3. Mexican standards for PAHs, BETEX and TPHs.

\begin{tabular}{|c|c|c|c|}
\hline \multirow[b]{2}{*}{ Parameter } & \multicolumn{3}{|c|}{ Maximum concentrations ( $\mathrm{mg} / \mathrm{kg}$ dry soil) } \\
\hline & $\begin{array}{c}\text { Agricultural } \\
\text { soil }\end{array}$ & $\begin{array}{l}\text { Residential } \\
\text { soil }\end{array}$ & $\begin{array}{c}\text { Industrial } \\
\text { soil }\end{array}$ \\
\hline \multicolumn{4}{|c|}{ TPHs } \\
\hline Light fraction & 200 & 200 & 500 \\
\hline Median fraction & 1200 & 1200 & 5000 \\
\hline Heavy fraction & 3000 & 3000 & 6000 \\
\hline \multicolumn{4}{|c|}{ BTEX } \\
\hline Benzene & 6 & 6 & 15 \\
\hline Toluene & 40 & 40 & 100 \\
\hline Ethylbenzene & 10 & 10 & 25 \\
\hline Xylene & 40 & 40 & 100 \\
\hline \multicolumn{4}{|c|}{ PAHs } \\
\hline Benzo (a) pyrene & 2 & 2 & 10 \\
\hline Dibenzo $(\mathrm{a}, \mathrm{h})$ antracene & 2 & 2 & 10 \\
\hline Benzo (a) antracene & 2 & 2 & 10 \\
\hline Benzo (b) fluorantrene & 2 & 2 & 10 \\
\hline Benzo (k) fluorantrene & 8 & 8 & 80 \\
\hline Inden $(1,2,3, \mathrm{~cd})$ pyrene & 2 & 2 & 10 \\
\hline
\end{tabular}


Table 4. TPH's and some PAH's present in the contaminated soils.

\begin{tabular}{cc}
\hline Parameter & Results $(\mathrm{mg} / \mathrm{kg})$ \\
\hline TPH's (heavy fraction) & 14,705 \\
Benzo (k) fluoranthene & 0.1280 \\
Benzo (a) pyrene & 0.0682 \\
\hline
\end{tabular}

Sulfopon 30, Tween 20, CAPB Polafix and mezquite seed gum with $59 \%, 54 \%, 52 \%$ and $55 \%$ of TPHs removal respectively. Zamudio-Pérez et al. [17] reported TPHs removals of $57.7 \%$ when washing an oil-contaminated soil, employing Brij 35 (Figure 2). They also tested natural gum as washing solutions. The best TPHs removal for natural gums was obtained with locust bean gum $(31 \%)$.

The second set of washing assessments different surfactant concentrations was carried out with the best of each type except mezquite seed gum. The last was replaced by guar gum because mezquite seed gum is not a commercial surfactant and its production method is complex. Three concentrations for every surfactant were evaluated in the second washing procedure. It was observed that Sulfopon $30(0.5 \%)$ achieved the highest percentage of removal $60 \%$.

Tween 20 (TW20) rendered removal efficiencies of $20 \%, 54 \%$ and $55 \%$ with solutions of $0.25 \%, 0.5 \%$ and $1 \%$ respectively. CAPB showed similar behavior, in this case, removals of $53 \%$ and $54 \%$ were achieved using concentration of $0.5 \%$ and $1 \%$ (Figure 3).

Regarding the TPHs removal efficiency using guar gum, it was observed that the concentration of $0.1 \%$ produced the best result, reaching 54\%. Same result as in the first wash. It is noteworthy that although it was not the highest removal percentage the experimental set showed the greatest amount of TPHs removal per gram of product (Figure 4), as the washing solutions used has lower concentration than synthetic ones.

In experiments made before, the standard deviations were not over the $5 \%$, in this experiment the analysis showed the same behavior.

\subsection{Characterization of the Generated Wastewaters}

The scaling-up of the washing process were carried out at the best conditions. In order to do that $16 \mathrm{k}$ of soil were washed with Sulfopon 30 at $0.5 \%$. Approximately, $40 \mathrm{~L}$ of wastewater were produced and characterized in terms of $\mathrm{COD}, \mathrm{BOD}_{5}$, turbidity, electrical conductivity, color, hardness, MABS (methylene blue active substances), oils and greases, as well as 4 selected metals. Results are depicted in Table 5. As shown COD value was above 1300

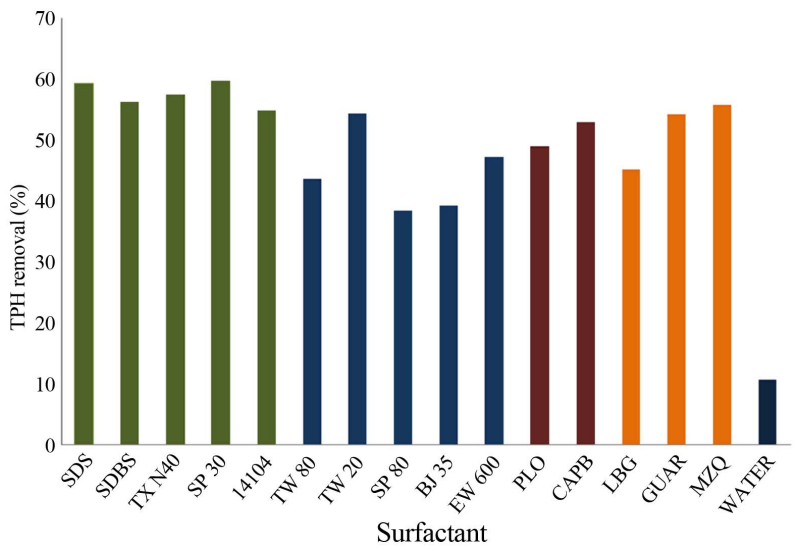

Figure 2. TPHs removals for the 15 washing solutions and water.

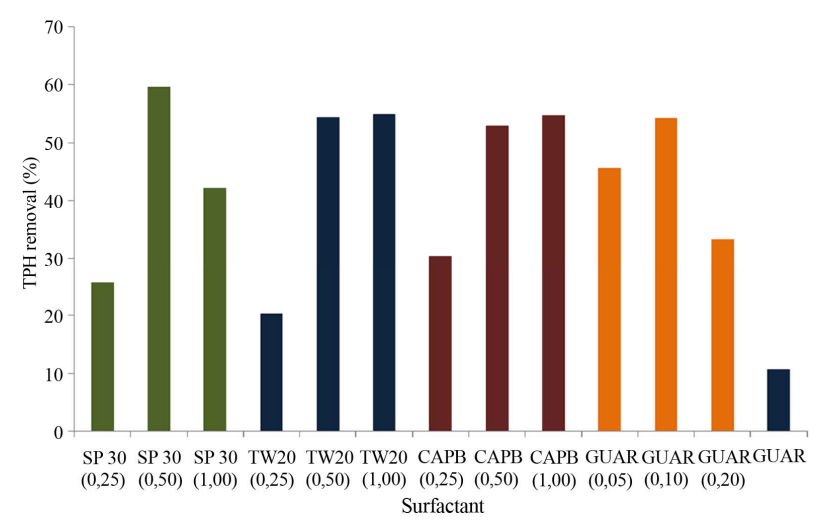

Figure 3. TPH's removals when using different surfactants concentrations for SP30, TW20 and guar gum.

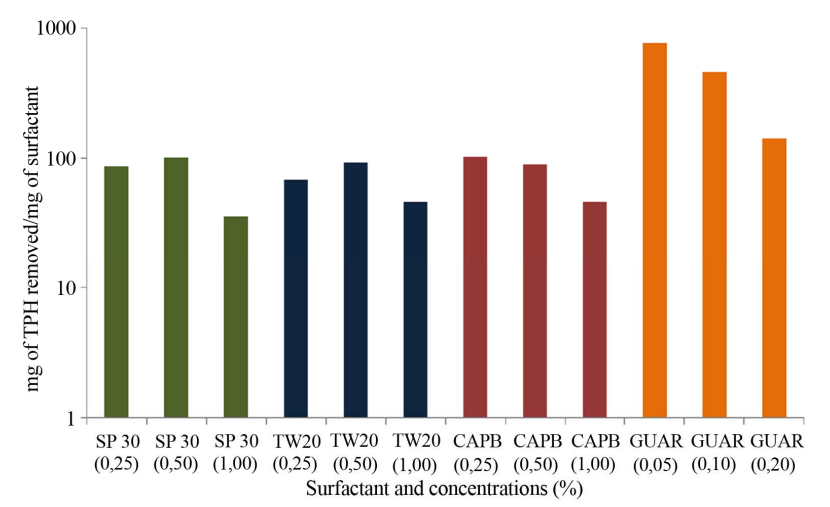

Figure 4. TPH's removals per mg of surfactant employed.

$\mathrm{mg} / \mathrm{L}$ which is below the reported by Bandala et al. [18] for refinery wastewater. Measured of BOD concentration was $380 \mathrm{mg} / \mathrm{L}$ generating a $\mathrm{BOD}_{5} / \mathrm{COD}$ ratio of 0.29 rating the wastewater as poorly biodegradable. Torres $e t$ al. [19] reported a rate of biodegradation on $41.7 \%$ (moderately biodegradable) of soil washing waste water from a site contaminated with hydrocarbons. The higher COD and BOD values obtained are due to the oil content 
Table 5. Characteristics of the produced wastewater.

\begin{tabular}{cccc}
\hline Parameter & Result & $\begin{array}{c}\text { Zamudio Perez } \\
\text { et al. [17] }\end{array}$ & Torres et al. [3] \\
\hline COD & $1329 \mathrm{mg} / \mathrm{L}$ & $1468.0 \mathrm{mg} / \mathrm{L}$ & $20,153 \mathrm{mg} / \mathrm{L}$ \\
BOD $_{5}$ & $385 \mathrm{mg} / \mathrm{L}$ & $289.6 \mathrm{mg} / \mathrm{L}$ & $8410 \mathrm{mg} / \mathrm{L}$ \\
BOD $_{5} / \mathrm{COD}$ & 0.29 & 0.197 & 0.41 \\
Turbidity & $1540 \mathrm{FAU}$ & $525 \mathrm{UNT}$ & $\mathrm{NR}$ \\
Conductivity & $1107 \mu \mathrm{S}$ & $2580.0 \mu \mathrm{S}$ & $1,353 \mu \mathrm{S}$ \\
Color & $92 \mathrm{Pt} / \mathrm{Co}$ & $3625 \mathrm{Pt} / \mathrm{Co}$ & $\mathrm{NR}$ \\
Hardness as CaCO & $489 \mathrm{mg} / \mathrm{L}$ & $22.50 \mathrm{mg} / \mathrm{L}$ & $337.31 \mathrm{mg} / \mathrm{L}$ \\
MBAS & $122 \mathrm{mg} / \mathrm{L}$ & $0.015 \mathrm{mg} / \mathrm{L}$ & $3368.0 \mathrm{mg} / \mathrm{L}$ \\
Oil and greases & $212 \mathrm{mg} / \mathrm{L}$ & $6.0 \mathrm{mg} / \mathrm{L}$ & $94.5 \mathrm{mg} / \mathrm{L}$ \\
Pb & $0.401 \mathrm{mg} / \mathrm{L}$ & $20.13 \mathrm{mg} / \mathrm{L}$ & $1.11 \mathrm{mg} / \mathrm{L}$ \\
Fe & $19.05 \mathrm{mg} / \mathrm{L}$ & $11.25 \mathrm{mg} / \mathrm{L}$ & $289.64 \mathrm{mg} / \mathrm{L}$ \\
$\mathrm{Cr}$ & $0.07 \mathrm{mg} / \mathrm{L}$ & $0.023 \mathrm{mg} / \mathrm{L}$ & $1.25 \mathrm{mg} / \mathrm{L}$ \\
$\mathrm{Al}$ & $24.21 \mathrm{mg} / \mathrm{L}$ & $23.62 \mathrm{mg} / \mathrm{L}$ & $429 \mathrm{mg} / \mathrm{L}$ \\
\hline
\end{tabular}

*When using TW80.

in the soil and the surfactant used in the washing procedure.

Differences in organic content for the wastewaters produced in this work, and those reported by Torres et al. [19] are significant. Nevertheless, it is important to remark that the produced wastewater characteristics will derive from several factors, i.e., 1) the soil type (sandy, loamy, clayey); 2) the contaminant type (light, medium, or heavy fractions in the case of oil derivatives); 3) the history of the contaminated soil, subjected to aging processes (young versus old spills); 4) the efficiency of the washing system (surfactant type and concentration, soil/ water ratio, energy input).

As observed, similar values for conductivity, hardness, the four selected metals and even for oil and greases were found. Important differences can be observed between the wastewaters generated in this work, and those reported by Torres et al. [19], when comparing COD (15 fold), BOD (21.8 fold) and the BOD/COD value (1.4 fold). It is interesting to note that MABS and oil and greases values were rather different (27.6 and 0.44 fold, respectively).

There is very little information on quality of wastewaters produced during the washing of contaminated soils; however, the characterization of these effluents is relevant regarding its treatment $[17,19,20]$.

\section{Conclusions}

In the selection of a surfactant for a washing soil, it could be helpful to propose different type of surfactants to identify the higher removal of the contaminant. Also it is necessary to establish the concentration of the surfactant at the greater removal.

The removal of TPH's by soil washing vary for each type of surfactant, in this case, the greater removals were observed after using the SP30, however when looking at the milligrams of TPH removed for each gram of surfactant employed, the natural gum removed more TPH, because the concentrations required were five times lower. The characterization of the resulting water is relevant due to the treatment as suggested of the high rates of removal of TPH's also the containing of the surfactant used in the washing process.

Our research group is working on the treatment of the generated wastewaters in a low-cost packaging material submerged biofilter inoculated with hydrocarbon-degrader microorganisms isolated from the original contaminated soil. Besides, the changes in the biofilter micro-flora due to the system operation (i.e., residence time, wastewater COD initial concentration and surfactant concentration) are being evaluated using DGGE technology.

\section{Acknowledgements}

Authors thank to S. Martinez and C. Serrano (Laboratorio de Calidad de Agua y Residuos UAM-Azcapotzalco) because their help in the soil sampling procedure. The help of C. Orozco (UPIBI-IPN) in the production of the wastewaters in an agitated tank is also acknowledged. This work was financially supported by SEP-CONACyT (Grant 084080).

\section{REFERENCES}

[1] S. Paria, "Surfactant-Enhanced Remediation of Organic Contaminated Soil and Water," Advances in Colloid and Interface Science, Vol. 138, No. 1, 2007, pp. 24-58.

[2] L. G. Torres, J. L. Orantes and R. Iturbe, "Three Surfactants CMC and Diesel Removal Efficiencies from Highly Contaminated Sandy Soils Environment," Geoscience, Vol. 1, 2003, pp. 28-36.

[3] L. G. Torres, J. Orantes and L. R. Iturbe, "Biodegradation of Two Nonionic Surfactants Used for in Situ Flushing of Oil-Contaminated Soils," Environmental Chemistry, Vol. 43, No. 5, 2006, pp. 251-255.

[4] E. R. Bandala, Y. Velasco and L. G. Torres, "Decontamination of Soil Washing Wastewater Using Solar Driven Advanced Oxidation Processes," Hazardous Materials, Vol. 160, No. 2, 2008, pp. 402-407. doi:10.1016/j.jhazmat.2008.03.011http://dx.doi.org/10.10 16/j.jhazmat.2008.03.011

[5] M. M. Parnian and S. Ayatollahi, "Surfactant Remediation of LNAPL Contaminated Soil; Effects of Adding Alkaline and Foam Producing Substances," Iranian Jour- 
nal of Chemical Engineering, Vol. 5, No. 2, 2008, pp. 34-44.

[6] R. Iturbe, R. M. Flores, C. Flores and L. G. Torres, "TPHContaminated Mexican Refinery Soil: Health Risk Assessment and the First Year of Changes," Environmental Monitoring and Assessment, Vol. 91, No. 1, 2004, pp. 237-255. http://dx.doi.org/10.1023/B:EMAS.0000009239.55534.08

[7] W. Chu, "Remediation of Contaminated Soils by Surfactant-Aided Soil Washing," Practice Periodical of Hazardous, Toxic and Radioactive Waste Management, Vol. 7, No. 1, 2003, pp. 19-24. http://dx.doi.org/10.1061/(ASCE)1090-025X(2003)7:1(1 9)

[8] L. G. Torres, X. Lemus, G. Urquiza, A. Verdejo and R. Iturbe, "Surfactant Enhanced Washing of Drilling Fluids, a Promising Remediation Technique, Tenside Surfactant," Detergent, Vol. 46, 2005, pp. 347-355.

[9] M. Han, G. Ji and J. Ni, "Washing of Fuel Weathered Crude Oil Contaminated Soil with an Environmentally Compatible Surfactant, Alkyl Polyglucoside," Chemosphere, Vol. 76, No. 5, 2009, pp. 579-586. http://dx.doi.org/10.1016/j.chemosphere.2009.05.003

[10] K. Urum and T. Pakdemir, "Evaluation of Biosurfactant for Crude Oil Contaminated Soil Washing," Chemosphere, Vol. 57, No. 9, 2004, pp. 1139-1150. http://dx.doi.org/10.1016/j.chemosphere.2004.07.048

[11] L. Chin-Chi, H. Yi-Chien, W. Yu-Hong and C. Jo-Chu, "Biosurfactant-Enhanced Removal of Total Petroleum Hydrocarbons from Contaminated Soil," Hazardous Materials, Vol. 167, No. 1-3, 2009, pp. 609-614. http://dx.doi.org/10.1016/j.jhazmat.2009.01.017

[12] A. Kalali, T. Ebadi, A. Rabbani and S. S. Moghaddam, "Response Surface Methodology Approach to the Optimization of Oil Hydrocarbon Polluted Soil Remediation Using Enhanced Soil Washing," Environmental Science and Technology, Vol. 8, No. 2, 2011, pp. 389-400.

[13] E. Tiezzi, C. A. Brebbia, S. E. Jorgensen and D. A. Gomar, "Ecosystems and Sustainable Development V," WIT Press, Southampton, Boston, 2005.
[14] E. Zamudio, "Biological Treatment of Wastewater Generated in the Washing of Soil Contaminated with Petroleum Hydrocarbons," M.Sc. Thesis, Biotechnology Interdisciplinary Professional, 2010.

[15] A. H. Bogardt and B. B. Hemmingsen, "Enumeration of Phenentrene-Degrading Bacteria by and Overlayer Technique and Its Use in Evaluation of Petroleum-Contaminated Sites," Applied and Environmental Microbiology, 1992, pp. 2579-2582.

[16] A. Hernández-Espriú, E. Sánchez-León, P. Martínez-Santos and L. G. Torres, "Remediation of Diesel-Contaminated Soil from a Pipeline Accidental Spill: Enhanced Biodegradation and Soil Washing Processes Using Natural Gums and Surfactants," Journal of Soils and Sediments, Vol. 13, No. 1, 2013, pp. 152-165. http://dx.doi.org/10.1007/s11368-012-0599-5

[17] E. Zamudio-Pérez, M. Vaca, E. R. Bandala, L. C. Fernandez and L. G. Torres, "Integrated Surfactant Enhanced Washing of a Soil Highly Contaminated with Petroleum Hydrocarbons and Treatment of the Generated Wastewaters Using an Aerobic Biofilter," Chemosphere, 2013.

[18] E. R. Bandala, J. B. Tiro, M. Luján, J. L. Sánchez-Salas and L. G. Torres, "Hydrocarbon Removal and Toxicity Reduction from Oil Industry Wastewater Using a Packed Aerobic Biofilter," Journal of Water and Health, 2013

[19] L. G. Torres, C. Belloc, M. Vaca, R. Iturbe and E. Bandala, "Coagulation-Flocculation Process Applied to Waste Waters Generated in Hydrocarbon-Contaminated Soil Washing: Interactions among Coagulant and Flocculant Concentrations and pH Value," Journal of Environmental Science and Health Part A, Vol. 44, No. 13, 2009, pp. 1449-1456. http://dx.doi.org/10.1080/10934520903217716

[20] T. T. Tsai, C. M. Kao, R. Y. Surampalli and S. H. Liang, "Treatment of Fuel-Oil Contaminated Soils by Biodegradable Surfactant Washing Followed by Fenton-Like Oxidation," Environmental Engineering, Vol. 135, No. 10, 2009, pp. 1015-1024 http://dx.doi.org/10.1061/(ASCE)EE.1943-7870.0000052 